\title{
ACADEMIC INTEGRITY WITH REFERENCE TO PLAGIARISM: A STUDY IN SENIOR SCHOOL
}

\author{
S. Nagaraju \\ Research Scholar, Osmania University, Hyderabad, India
}

\begin{abstract}
This paper deals with the academic integrity practices in student community. Academic Integrity is now a day a hot topic in academic field. In academic community students are simply copying the text from the sources without giving credit to the original works. Rapid development of internet caused the growth of Academic Disintegrity in students. And the benefit of computer science solved to detect plagiarism. Recently many universities have adapted academic integrity policies and made it compulsory to check plagiarism for student works.
\end{abstract}

Keywords: Academic integrity, Academic disintegrity, Plagiarism, Citation, Referencing, academic integrity, Citation styles.

Cite this Article: S. Nagaraju, Academic Integrity with reference to plagiarism: A study in senior school, International Journal of Library \& Information Science, 7(1), 2018, pp. 20-27.

http://iaeme.com/Home/issue/IJLIS?Volume=7\&Issue=1

\section{INTRODUCTION}

Academic Disintegrity means not practicing academic integrity. Academic disintegrity deals with the attempted or unauthorized use of materials, information, notes, study aids, devices or communication during an academic exercise.

Plagiarism is the act of presenting another person's ideas, research or writing as your own. Academic Disintegrity deals the obtaining an Unfair Advantage and Stealing, reproducing, circulating or otherwise gaining prior access to examination materials and confidential data. Academic Disintegrity also deals with the act of falsification of Records and Official Documents, forging signatures of authorization, Falsifying information on an official academic record or an official document such as a grade report, letter of permission, drop/add form, ID card or other college document. 


\subsection{Why students should practice Academic Integrity?}

- It helps them establish and maintain trust with instructors.

- Students who cheat or plagiarize risk negative consequences, such as grade deductions, suspension or expulsion from a school.

- Academic integrity ensures that a student gets credit for his own work and receives constructive feedback on his own work.

- Self-respect and self-confidence.

- Better skills and a more accurate sense of where your strengths and deficiencies lie.

- It helps you to shape your personalities.

- Provide credit to those who worked for it not to those who cheat.

- Will make you truthful and reliable in your life time.

- It teaches you to become responsible.

- Help them to keep pursuing their educational goals with dignity, integrity and admiration for school campus.

\subsection{Citing and referencing:}

Citing and referencing deals with the original work. It gives credit to original author. Citation can be defined in text citation and foot note or bibliographical referencing list. There are some standard styles deals citation and reference. MLA, Harvard, IEEE, APA, Chicago etc.

\section{Why -}

- To give credit to another author ideas and theory.

- Understand the concepts and know who has written about them.

- To allow your reader to find and examine your sources.

- Information to verify your source.

- To find more information on the subject.

- To Measure the influence of one thinker upon another.

\section{What not to cite -}

- Common knowledge facts.

- Statistical information widely available in all sources that are not vary from source to source.

- Commonly known encyclopedia and dictionary definitions.

\section{When -}

- Restate an ideas and thesis of an author.

- Restate an expert's theory and opinion.

- Facts are not common knowledge, for information and explanatory notes.

- You also must cite for restatements of authors summary and paraphrase.

\subsection{Plagiarism:}

Plagiarism means failing to acknowledge the sources of others work in our creative works whether intentionally or unintentionally. Plagiarism is considered academic disintegrity and can constitute copyright infringement. 
- Self-Plagiarism - Submitting the personal work more than once to other purpose done by same without proper permission from the teachers involved.

- Collusion: Helping someone else to plagiarize by letting them submit your work as their own

\section{REVIEW OF LITERATURE:}

Academic integrity, with Internet plagiarism as one of the most common forms, is a concern on college and university campuses more than ever before. In India, Dravdian Universit, Kuppam a state university of Andhra Pradesh rejected 427 research theses and dissertations in all subjects during 2008-2016, because of plagiarism is more than $30 \%$ (www.dravidianuniversity.ac.in).

According research study of public and private colleges and universities in USA, conducted by Donald L. McCabe (2004), thirty-eight percent of the undergraduate students surveyed indicated that they had engaged in Internet plagiarism. According to Facts about Plagiarism, 2011 report by Education week survey, 54\% admitted to plagiarism by using internet and $76 \%$ committed to cheating and $80 \%$ of students committed to cheating at least once ("Facts About Plagiarism," 2011).

Josephson institute center for youth ethics surveyed 43,000 high schools in USA in 2009, resulted that $59 \%$ of students admitted to cheating in test in 2009 and 34\% students self reported two or more times(http://josephsoninstitute.org/surveys/).

In May 2006, Department of Mechanical Engineering, Ohio University reviewed 34 masters' thesis and found that thesis are committed to plagiarism.

Donald L McCabe(2010) of Rutgers University, NJ, USA, surveyed 24,000 students in 70 schools in 2010 result shows that $64 \%$ of students cheated in test, $58 \%$ admitted to plagiarism and $95 \%$ admitted to cheating in academic works. He also conducted 63,700 undergraduate and 9,250 graduate students for three years course period (2002-05) resulted that $36 \%$ of undergraduate and $24 \%$ of graduate students committed plagiarism by copying text form internet and $38 \%$ of undergraduate and $25 \%$ of graduate students committed plagiarism by copying text form print or written documents. Also the report shows that $7 \%$ of undergraduate and $3 \%$ of graduate students used others work as their own.

\section{OBJECTIVE OF THE STUDY:}

Objective of the study is:

- To promote the concept of academic integrity in schools.

- To review the academic integrity policy in academic institutions.

- To prevent academic dishonest in schools.

- To develop policies, procedures and expectations of students to academic integrity.

\section{METHODOLOGY:}

The purpose of the study is to find what extent the students are participating in academic integrity in their academic work. DRS International School, Kompally, Hyderabad is practicing school academic integrity policy. A study about academic integrity was conducted with a group of 64 senior students of DRS International School enrolled in 2015. This paper surveyed on academic integrity in school community to prevent the academic disintegrity. 


\subsection{The survey was designed to answer to find the questions:}

- What is the percentage of students engaged with academic disintegrity?

- What percentage of students engaged with Internet plagiarism?

- What are the reasons of students to engage in academic disintegrity?

- What is the role of librarian in student participation of academic integrity?

- How much knowledge student have on proper acknowledgement?

Table 1 Profiles of respondents.

\begin{tabular}{|c|c|c|}
\hline Section & Male & Female \\
\hline Class XI & 19 & 12 \\
\hline Class XII & 24 & 9 \\
\hline Total & $43(67 \%)$ & $21(33 \%)$ \\
\hline \multicolumn{2}{|c|}{ Grand Total } & $64(100 \%)$ \\
\hline
\end{tabular}

\subsection{What is the percentage of students engaged with academic disintegrity?}

The Examiners view Academic disintegrity of students by the Referencing \& citing styles they used, list of works cited, by In-text citation, references and bibliographies mentioned, the quality of sources used.

Using computers technology academic disintegrity can be identified by the formatting styles used, examining online sources with tools and techniques, by searching suspicious sections of papers, using plagiarism detector (e.g., Turnitin, Plagiarism.org, Safeassign etc.,)

Table 2 Students and plagiarism percent of their work.

\begin{tabular}{|c|c|c|}
\hline S. No & No. of students & $\begin{array}{c}\text { Percentage of plagiarism } \\
\text { (As per Turnitin Report 2015-2016) }\end{array}$ \\
\hline 1 & 6 & $>20$ \\
\hline 2 & 15 & $20<>30$ \\
\hline 3 & 18 & $30<>60$ \\
\hline 4 & 16 & $60<>80$ \\
\hline 5 & 9 & $80<$ \\
\hline
\end{tabular}

In DRS International School as per school academic integrity policy every senior school student work should submit to Turnitin a plagiarism detecting online tool to check what percent of work is plagiarized. And as per Turnitin report, 2015-2016 for senior school students results that 84 percent student intentionally committed to academic disintegrity. In this 84 percent 20 percent students have no idea about academic integrity policies and procedures.

\subsection{What percentage of students engages with Internet plagiarism?}

Exploring of internet resources in the present environment is allowed in increasing plagiarism in student community. They simple copying and pasting text of others work as their own work without citation and referencing. This situation created to practice academic integrity policies and technology helped to develop tools to find plagiarism. DRS International School using Turnitin a online plagiarism finding tool to find plagiarism of students work.

Table number 1 showing that only21 students out of 64 are eligible to submit their academic work as per school academic integrity policy (Maximum of 30\% plagiarism is 


\section{S. Nagaraju}

accepted as per school academic integrity policy). $40 \%$ of students are admitted that they do not know how to cite and reference.

Table 3 The number of students and type of plagiarism

\begin{tabular}{|c|c|c|c|}
\hline $\begin{array}{c}\text { S. } \\
\text { No }\end{array}$ & $\begin{array}{c}\text { Plagiarism } \\
\text { percent }\end{array}$ & $\begin{array}{c}\text { Internet } \\
\text { sources }\end{array}$ & $\begin{array}{c}\text { Other } \\
\text { sources }\end{array}$ \\
\hline 1 & $>20$ & 4 & 2 \\
\hline 2 & $20<>30$ & 11 & 4 \\
\hline 3 & $30<>60$ & 15 & 3 \\
\hline 4 & $60<>80$ & 14 & 2 \\
\hline 5 & $80<$ & 9 & 0 \\
\hline
\end{tabular}

\subsection{What are the reasons for students to engage in academic disintegrity?}

As per results, the table number 2 shows that 45 percent students are saying that all other friends and schoolmates are copying and pasting text form internet, so I did the same. Nearly 50 percent students are lack of understanding academic integrity policies and procedures these students need training and help in practicing academic integrity.

Table 4 Reasons for engaging students in academic disintegrity

\begin{tabular}{|c|c|c|}
\hline S.No & $\begin{array}{c}\text { Reasons caused for } \\
\text { Academic disintegrity }\end{array}$ & Percentage \\
\hline & For Grades & $96 \%$ \\
\hline & Busy or no time & $12 \%$ \\
\hline & No subject knowledge & $18 \%$ \\
\hline $\begin{array}{c}\text { No proper } \\
\text { Training/guidance /help }\end{array}$ & $40 \%$ \\
\hline $\begin{array}{c}\text { Everyone does it, so I } \\
\text { also did }\end{array}$ & $45 \%$ \\
\hline $\begin{array}{c}\text { Lack of understanding } \\
\text { academic integrity } \\
\text { policy }\end{array}$ & $54 \%$ \\
\hline
\end{tabular}

Preventing the academic disintegrity in schools involves:

- Proper citing \& referencing.

- Study concepts and ideas of different authors work and compare.

- Write in your own words, do not copy and paste.

- Try to add different words instead of using regular words.

- Use plagiarism detecting tools.

\subsection{What is the role of library in student participation of academic integrity?}

Based on the below questions I had tried to find the important role if Librarians in academic integrity. Results show that most of the students are approaching teacher/facilitator to find the resources for their academic work. 


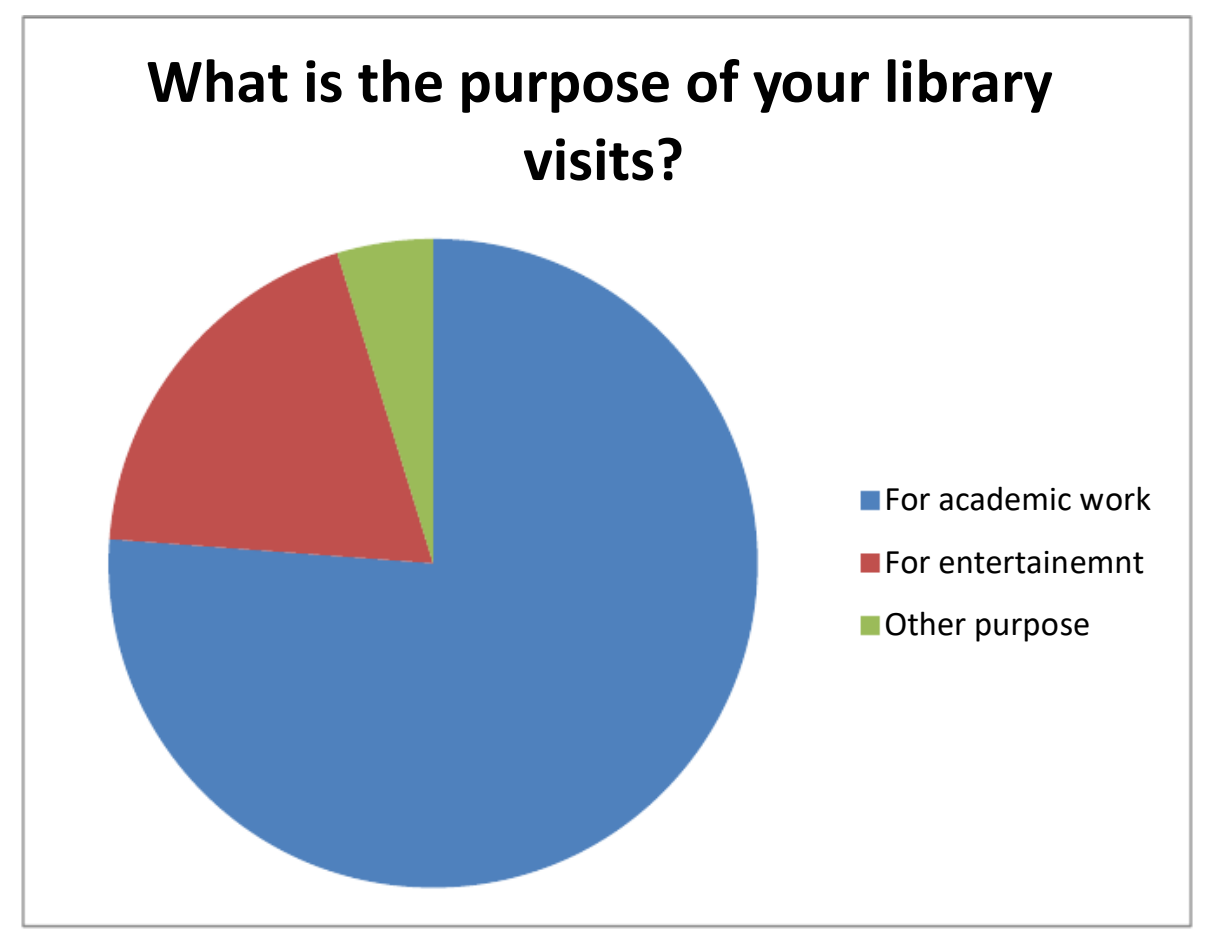

Figure 1 Students purpose of library visit

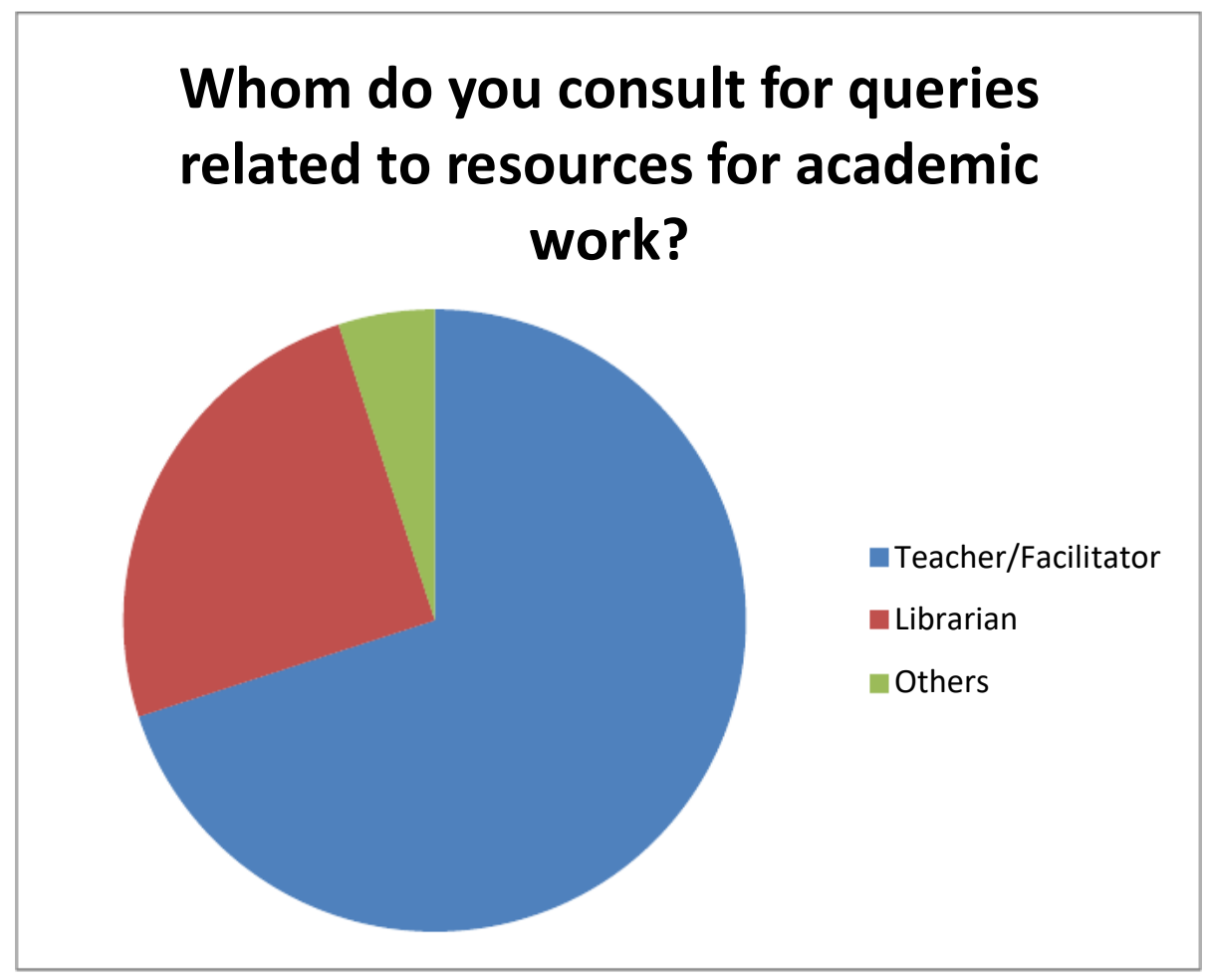

Figure 2 Students Consultation of academic works resources 


\section{Where do you access resources for your academic work?}

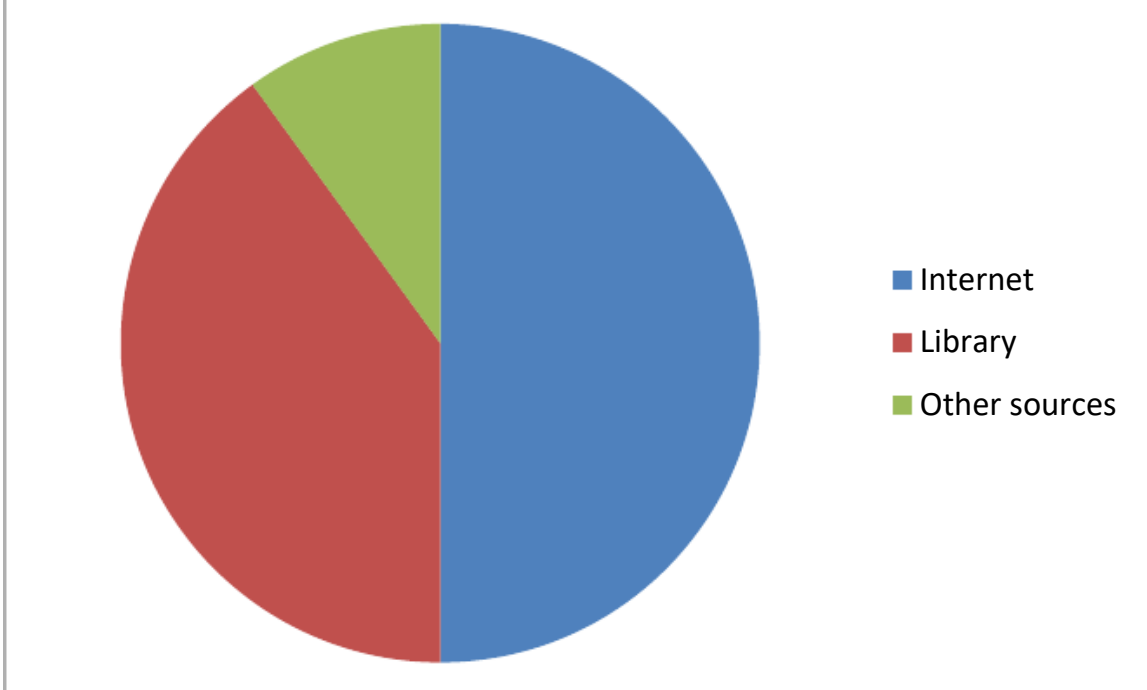

Figure 3 Resources accessing of student academic work

\subsection{How much knowledge student have on proper acknowledgement?}

A Proper acknowledges means to acknowledge the work of others in your assignment by using citation and referencing.

When you paraphrase someone's ideas you need to include an in-text citation and an entry in the reference list

When you quote someone's exact words you also need to include quotation marks around their words (" ") and a page reference for the quoted passage.

The below questioner results the most of the student they do not know much about school academic policy. The new concept of internet citing should be trained to student and staff.

Table 5 Questions for Students response on academic integrity practices

\begin{tabular}{|c|c|}
\hline Q1 & $\begin{array}{c}\text { Do you know academic integrity is a } \\
\text { punishable affiance under school } \\
\text { academic integrity policy? }\end{array}$ \\
\hline Q2 & $\begin{array}{c}\text { Do you acknowledge if you copy } \\
\text { others works? }\end{array}$ \\
\hline Q3 & $\begin{array}{c}\text { Do you know how to cite internet } \\
\text { sources? }\end{array}$ \\
\hline Q4 & $\begin{array}{c}\text { Do you know there are some tools to } \\
\text { detect plagiarism? }\end{array}$ \\
\hline
\end{tabular}




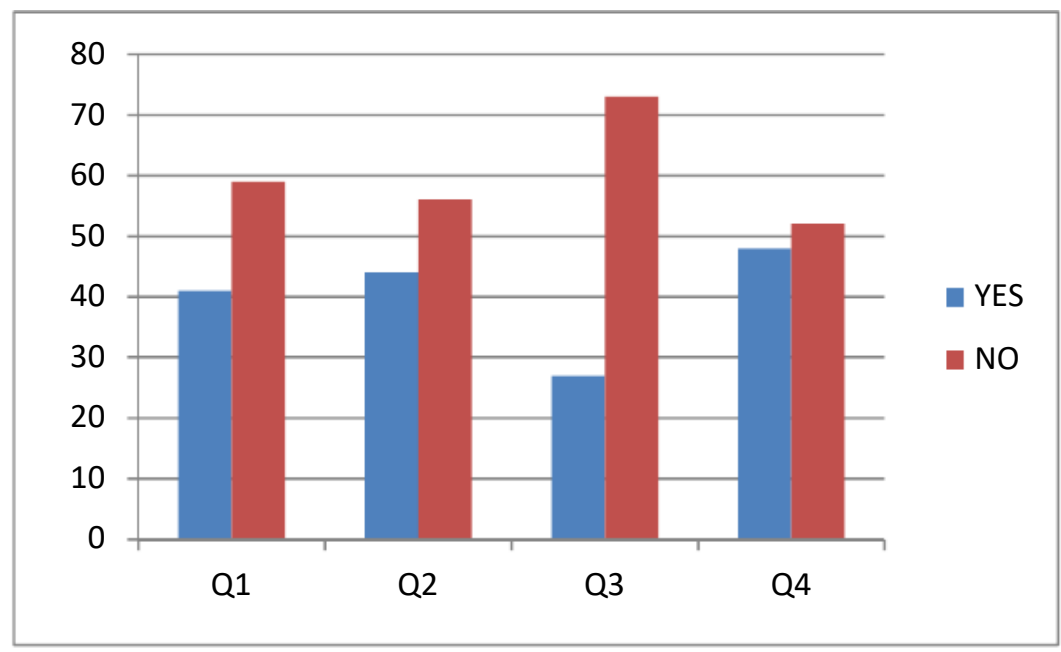

Figure 4 Students response on academic integrity practices

\section{CONCLUSION:}

The present scenario of availability of internet resources increased academic disintegrity in student community. There is a strong need to implement academic integrity policies in academic institutions. Many students as well as teachers they do not know the concept of academic integrity so they need training. The libraries should play an important role in this area to help students and teachers in citation and referencing. The new concept of internet citing should be trained in academic institutions. Academic disintegrity can be prevented by proper citing and referencing.

\section{REFERENCES:}

[1] Donald L. McCabe and Gary Pavela. Principles of Academic Integrity: How Faculty Can Foster Student Honesty, Taylor \& Francis, May - June 2004, Vol. 36, No. 3, pp. 10-15.

[2] Jones, D.L. (2011). Academic dishonesty: Are More Students Cheating? Business Communication Quarterly, June 2011, Vol. 74, No. 2, pp.141-150, DOI: 10.1177/1080569911404059.

[3] Evans, E. D. \& Craig, D. (1990). Teacher and student perceptions of academic cheating in middle and senior high schools. Journal of Educational Research, 1990, 84, pp.44-52.

[4] Facts about Plagiarism, 2011. Available: http://www.plagiarism.org/resources/facts-andstats .

[5] Josephson Institute of Ethics Releases Study on High School Character and Adult Conduct. Available: http://josephsoninstitute.org/surveys.

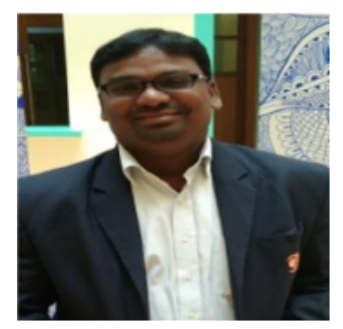

S. Nagaraju was born in Hyderabad, Telangana state in India in 1981. $\mathrm{He}$ received the B.Sc. and M.Sc. degrees in Mathematics. He also completed his mater degree in Library and Information Science (M.L.I.Sc.) from Osmania University in 2006.

In his 11 years experiance, he worked as librarian for Engineering college and Scool. He had a credit of 14 article publications in journals and conferences in the filed of Library and Information Science. He is pursuing Ph.D in library and information Science and his research interests include Digital Libraries, Library Automation, Electronic Resources, Institutional Respositaries.

Mr. Nagaraju ranked first in University for his Masters in Library \& Information Science and baggedd University Gold Medal from Osmania University in 2006. 